\title{
Future Benefits of Microorganism on Leather Defects in The Industrial Production of Protease
}

\author{
Novita Kurniawati ${ }^{1}$, Eka Lusiana $^{2}$, Nanung Agus Fitriyanto ${ }^{1}$, Mohammad Zainal Abidin $^{1}$, \\ Satyaguna Rakhmatulloh ${ }^{1}$, Yuny Erwanto ${ }^{1}$, Zaenal Bachruddin ${ }^{1}$, Rusman $^{1}$, Lies Myra \\ Yusiati $^{1}$, Ambar Pertiwiningrum ${ }^{1 *}$ \\ ${ }^{1}$ Univeritas Gadjah Mada, Indonesia \\ ${ }^{2}$ Balai Besar Kulit, Karet, dan Plastik Yogyakarta, Indonesia
}

\begin{abstract}
Article, pickle, and wet blue leather defects used for this study were from the Balai Besar Karet college, Kulit dan Plastik, D.I Yogyakarta (BBKKP YK), Indonesia. Meanwhile, the microorganisms in leather defects were grown in vitro at A-minimal mineral (MM) and B-lowest (1/200 v/v) nutrient media. A nitrogen source of $2 \%$ Sigma-Aldrich bovine gelatine was added to each medium. Furthermore, $1 \mathrm{~cm}^{2}$ of each leather defect was sliced and immersed into the in vitro media for 7 days in an open-air rotary incubation with ambient temperature at $28^{\circ} \mathrm{C}$ to $30^{\circ} \mathrm{C}$. The first or conventional method was the rubbing of ose cotton into the solid media, while the second isolation method was the centrifugation of liquid growth medium at $15.1 \mathrm{G}$ for 20 minutes. Moreover, the four microbial isolates were from glossy yellow colonies A and B as well as white colonies. These colonies were incubated at $38^{\circ} \mathrm{C}$ and the four microbes produce proteases after growing for at least 7 days in liquid media and 24 hours less in solid media. The protease test produced gases on the pickle leather defects using a test tube glass of $0.8 \mathrm{~cm}$ diameter and $15 \mathrm{~cm}$ long. Therefore, the chemical tanning process on leather defects creates a unique ecosystem of microorganisms as collagen proteins change and become the key to their growth.
\end{abstract}

Keywords: BBKKP YK, article, pickle, wet blue leather.

\section{Introduction}

The studies on microbial growth on leather were carried out 3 decades ago and one of the results showed that bacteria grow to colonize and produce biofilms found in the facial holes of the growing hair follicles. Therefore, study on the growth of microbes with leather proteins that have been preserved with various tannery preservatives is important. Moreover, the growth of living things is determined by the ability of cell metabolism to reproduce and

* Correspondence author : $\underline{\text { artiwi@mail.ugm.ac.id }}$ 
rejuvenate. This metabolism involves a variety of functional proteins that are tasked with converting substrates from living media into sustainable intermediates to strengthen cells' existence and population.

Meanwhile, the leather defect is impossible even when it has absorbed various preservatives during the tanning process. Industrial leather is categorized into semi-finished leather such as pickle, wet blue or white, and post tanning leather or article. The pre-tanning process produces semi-finished leather with stages such as soaking, deharing, liming, deliming, batting, and pickling. The tanning and post tanning processes turn semi-finished leather into article leather by inserting and binding the tanning material in form of metal minerals, vegetables, oil, and syntans for the leather to experience different shrinkage, attractiveness, and softness from the raw material or the semi-finished leather (Purnomo, 1985) [2]. Moreover, the microorganisms grow and leave marks on both sides of the skin, causing unremovable stains or defects even at the repair or correction stages of the physical or chemical finishing stage. Therefore, leather defects due to incisions or tick bites are only disguised while the intensity of the color is different when the scars or tattoos on the leather are intact.

Defects in the hide/skin tannery by microorganisms are seen without the aid of optical instruments. The microbes that grow on the surface of the leather appear green to dark brown on the pickle leather, while the wet blue leather appears yellow like metal rust, and the article leather shows a translucent timepieces colony growing on both sides of the leather. Meanwhile, a previous conducted by B.H. Cadirci, H. Ozgunay C. Vural, and O. Yilmaz (2010) showed the microscopic images of bio-film microbes positions that covered the surface holes of the hair follicle, tanned skin, wet blue, and crust [1].

Fungi are microbes that cause a leather defect in the tanning process. In this study, there were leather defects in acidic skin (pickle), wet blue (half tanning), and article (finishing processed leather, upper shoe). Meanwhile, microorganisms that frequently cause leather defects include filamentous fungi of the genus Penicillium and Aspergillus as well as bacteria or yeasts [3]. The pickle and wet blue have high moisturization with an acidic $\mathrm{pH}$ value. During storage in unsuitable facilities, the leather easily got damaged by environmental and microbial conditions. This leather starts to break down by changing the $\mathrm{pH}$ and reducing the moisture compared to the microbes that easily contaminate the leather. When moisture and $\mathrm{pH}$ no longer support microbial growth, they are dormant and remain in the microstructure of the leather which becomes colored on the leather surface. The leather that has been bound with tanning chemicals such as wet blue and articles tainted by microbial Kapang (bahasa) or fungi are usually more dominant than bacteria and yeast $[1,4]$.

Extracellular protease is the main pathway for leather defect microbes to grow naturally on collagen proteins. The in vitro tested microbial leather defect in liquid and solid media provided similar artificial protein sources such as skimmed milk and gelatin. Furthermore, tanning or natural inhibitor compounds are used on microbes with leather defects to affect and stunt their growth. This method is a modification of previous studies $[4,5,6]$

Microbial metabolism of leather defect have lipids metabolomic because to keep the collagen fibers from drying out, oil penetration (fat liquefaction) is conducted at the post tanning stage. Hence, microbial leather defect requires metabolomics proteins and lipids simultaneously. Therefore, upper shoe finished article leather defect was used for this study.

The growth method of microbial leather defects was carried out by modifying the recipe growth medium of fungi /kapang from Shepherd et al., (2010), using yeast or bacteria with recipe media that had been tested by ATCC (2013) [8], Gautam, and Azmi ( 2017) [6], and Shepherd et al., (2010) [8]. Furthermore, slime-producing microbes or biofilms were contaminated in the leather defects based on a study by Nagano et al., 2008 [9]. Meanwhile, the microbial growth media are presented in Table 1. 
Microbial proteases have been widely used compared to animal organ proteases due to their easy modification. Meanwhile, the protease of microbes from leather is very unique because microbes are easily reproduced with inorganic sources such as nitrogen and carbon. These sources are from tanning materials in addition to collagen and liquefying fats when the free moisture content is limited. Microbial leather defects are often associated with pathogenic and harmful microbes so there is no benefit. Therefore, this study aims to identify the benefits of leather defects in microbial protease as a protein that promises to be functional in the future

Table 1. Medium Composition of Fungi, Yeast, and Bacteria

\begin{tabular}{|c|c|c|c|}
\hline Microbial & Kinds of Media & Compositions & References \\
\hline \multirow[b]{2}{*}{ Fungi } & TSB media $(1 \mathrm{~L})$ & $\begin{array}{l}\text { Tryptic Soy Broth } \\
30 \mathrm{gr}\end{array}$ & $\begin{array}{l}\text { Shepherd et al., } \\
\text { (2010) [8] }\end{array}$ \\
\hline & YEME media (1 L) & $\begin{array}{l}\text { Yeast extract } 3 \text { gr, } \\
\text { Peptone } 5 \text { gr, malt } \\
\text { extract } 3 \mathrm{gr} \text {, } \\
\text { glucose } 10 \mathrm{gr} \text {, } \\
\text { sugar } 10 \mathrm{gr} \text {, agar } \\
15 \mathrm{gr}\end{array}$ & $\begin{array}{l}\text { Shepherd et al., } \\
\text { (2010) [8] }\end{array}$ \\
\hline Yeast & $\begin{array}{l}\text { Medium B (1 L) } \\
\text { To sharpen the ability } \\
\text { and selectively add } \\
\text { inhibition } \\
\text { compounds/antibiotics }\end{array}$ & $\begin{array}{l}\text { Yeast extract } 30 \mathrm{gr} \\
\text { : peptone } 6.8 \mathrm{gr}, \\
\text { glucose } 16.7 \mathrm{gr}, \mathrm{pH} \\
6.3 \pm 0.2 \\
\text { Solid Medium } \\
\text { added with agar } 20 \\
\text { gr }\end{array}$ & $\begin{array}{l}\text { Nagano et al., } \\
(2008) \text { [9] }\end{array}$ \\
\hline $\begin{array}{l}\text { Yeast and } \\
\text { Fungal }\end{array}$ & $\begin{array}{l}\text { Sabouraud Dextrose } \\
\text { Agar (SDA) }\end{array}$ & $\begin{array}{l}\text { Peptone }(10.0 \mathrm{~g} / \mathrm{l}) \text {, } \\
\text { glucose }(40.0 \mathrm{~g} / \mathrm{l}), \\
\text { agar }(15.0 \mathrm{~g} / \mathrm{l}) \\
\text { make up to } \mathrm{pH} \\
5.6 \pm 0.2 .\end{array}$ & $\begin{array}{l}\text { Oxoid } \\
\text { CM0041, } \\
\text { Oxoid Ltd., } \\
\text { Basingstoke, } \\
\text { UK disitati } \\
\text { Nagano } \text { et al., } \\
\text { (2008) [9] }\end{array}$ \\
\hline $\begin{array}{l}\text { Collagenase } \\
\text { microbial }\end{array}$ & $\begin{array}{l}\text { Selective medium } \\
\text { without gelatine and } \\
\text { collagen }\end{array}$ & $\begin{array}{l}\text { Gelatine } 2.0 \%, \\
\text { agar } 1.5 \%, \mathrm{NaCl} \\
0.01 \%, \text { peptone } \\
0.5 \%, \mathrm{KH}_{2} \mathrm{PO}_{4} \\
0.05 \% ; \\
\mathrm{MgSO}_{4} \cdot 7 \mathrm{H}_{2} \mathrm{O} \\
0.02 \%, \mathrm{pH} 7.5\end{array}$ & $\begin{array}{l}\text { Gautam and } \\
\text { Azmi (2017) } \\
{[6]}\end{array}$ \\
\hline $\begin{array}{l}\text { Collagenase } \\
\text { microbial }\end{array}$ & $\begin{array}{l}\text { M-5 added collagen or } \\
\text { gelatine } 0.3 \%\end{array}$ & $\begin{array}{l}\text { Sucrose } 1.0 \% \text {, } \\
\text { extract yeast } 2.0 \% \text {, } \\
\text { peptone } 1.0 \% \text {, } \\
\mathrm{MgSO}_{4} .7 \mathrm{H}_{2} \mathrm{O} 0.04 \text {, } \\
\mathrm{Na}_{2} \mathrm{HPO}_{4} 0.2 \% \text {, } \\
\mathrm{Na}_{2} \mathrm{CO}_{3} 0.25 \%, \mathrm{pH} \\
7.5\end{array}$ & $\begin{array}{l}\text { Gautam dan } \\
\text { Azmi (2017) }\end{array}$ \\
\hline
\end{tabular}




\section{Materials and Methods}

\subsection{Leather Defect Sample and Microbial Comparison}

Leather defects samples were from the colleagues at Balai Besar Kulit, Karet, and Plastik Yogyakarta. The samples used were goat leather defects such as pickle, wet blue, and dark brown upper shoe. Furthermore, the number of sample pieces for isolation and incubation were cut into 3 to 4 different areas, each wrapped in a plastic bag and stored at $5{ }^{\circ} \mathrm{C}$ until the sample is used (Figure 1).

The maximum sample area cut into smaller pieces was $1 \mathrm{~cm} \times 1 \mathrm{~cm}$. Each sample was put into a $300 \mathrm{ml}$ Erlenmayer glass with $200 \mathrm{ml}$ of growth medium A and B. Meanwhile, cutting samples into smaller pieces helps microbial leather defects to dissolve easily in the liquid growth media. Furthermore, the samples were incubated at room temperature $28^{\circ} \mathrm{C}$ to $30{ }^{\circ} \mathrm{C}$ in the open-air rotary shaker for 7 days.

This confirmed that through microbial protease production compared with positive microbial protease production in $2 \%$, commercial skimmed milk of $1.5 \%$ agar was produced. The A Microbial isolates, $\mathrm{K}^{+}$no. 11 Penicillium crustosum, $\mathrm{K}^{-} / \mathrm{Gram}^{+}$Corynebacterium glutamicum, and K-/Gram-Rhodotorula glutinisi. The B Microbial isolates, $\mathrm{K}^{+}$no.9 Rhizobium sp., $\mathrm{K}^{-} / \mathrm{Gram}^{+}$no.3 Streptomyces achromogeness, and $\mathrm{K}^{-} / \mathrm{Gram}^{-}$no.15 MATOW6 (Streptomyces sp.putative). K is control ${ }^{+}$or $^{-}$protease production.
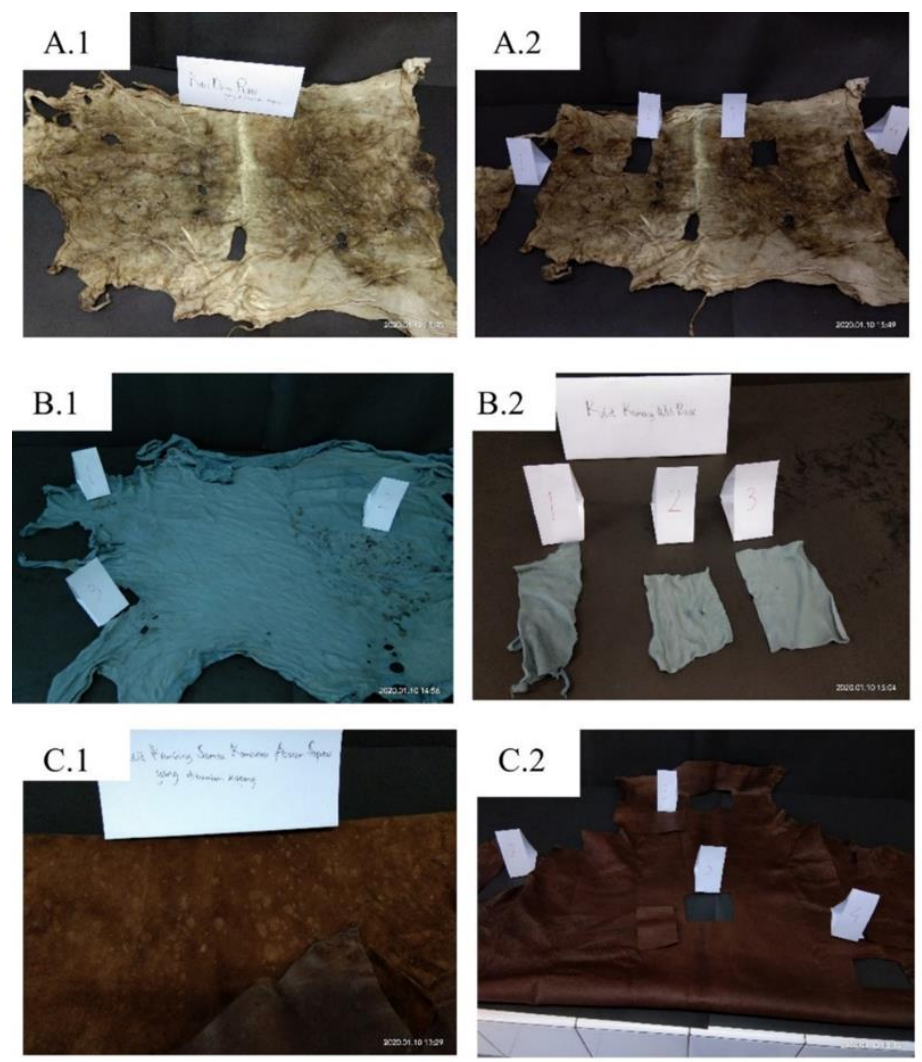

Fig. 1. Three types of leather defected by microbial. A. Pickle-type leather defect, B. Wet Blue-type leather defect, C. Article (Upper shoe) type leather defect. 


\subsection{Leather Defect Isolation Medium}

Microorganism leather defects were grown on minimal mineral media (A MM), the lowest $(1 / 200 \mathrm{v} / \mathrm{v})$ nutrient medium (B 1/200N). Furthermore, $2 \%$ of bovine Sigma-Aldrich gelatine was added to the media, and $1 \mathrm{~cm}^{2}$ of each leather defect was sliced into the smallest size for the microbes easily dissolve in the liquid media for 7 days in an open-air rotary incubation and ambient temperature of $28^{\circ} \mathrm{C}$ to $30^{\circ} \mathrm{C}$.

Medium A contains $\mathrm{K}_{2} \mathrm{HPO}_{4} 0.07 \%$. $\mathrm{KH}_{2} \mathrm{PO}_{4} 0,01 \%, \mathrm{MgCl}_{2} 0,02 \%$, and medium $\mathrm{B}$ contains 1/200 CM0001 OXOID. Both media were enriched with $2 \%$ bovine gelatine while the leather defect samples were immersed after being sterilized moderately and cooled at room temperature. The microscopic microbial leather defects are shown in Figure 2.
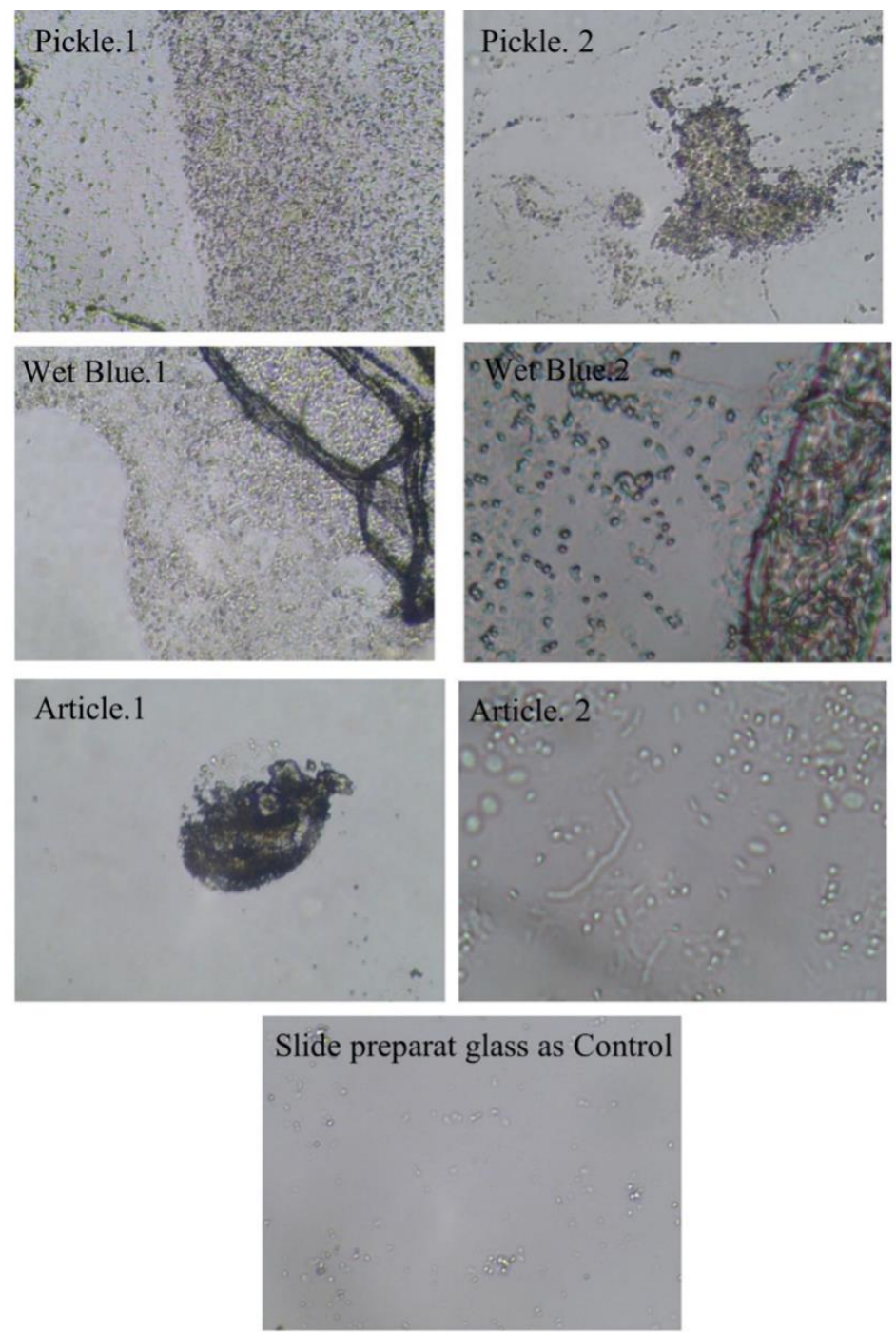

Fig. 2. Light microscope picture. The sediment cell leather defect microbia after grown 7 days. 


\subsection{Preparations for the Isolation of Leather Defects}

The two methods for microbial collection include the isolation of microbes from the source of leather defects which were grown on liquid medium A and B for 7 days rather than scratches. Secondly, liquid media methods A and B were centrifuged at $15.1 \mathrm{G}$ for 20 minutes, and the supernatant, as well as microbial cell sediment, were obtained. All fluids (first and second methods) were used as microbial sources of leather defects. The microbial leather defects as shown on A solid media include 1.5\% agar and nitrogen source, $2 \%$ gelatine, and commercial skimmed milk (Figures 3).
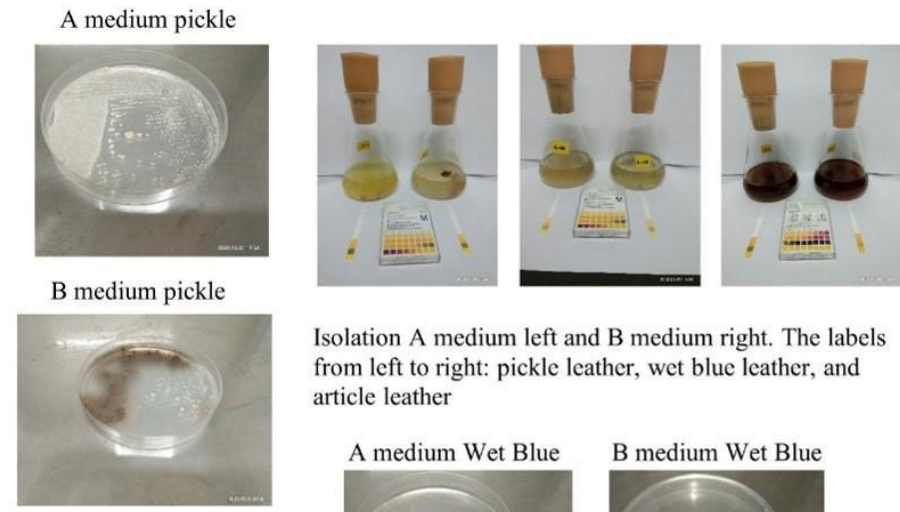

Isolation $\mathrm{A}$ medium left and $\mathrm{B}$ medium right. The labels from left to right: pickle leather, wet blue leather, and article leather
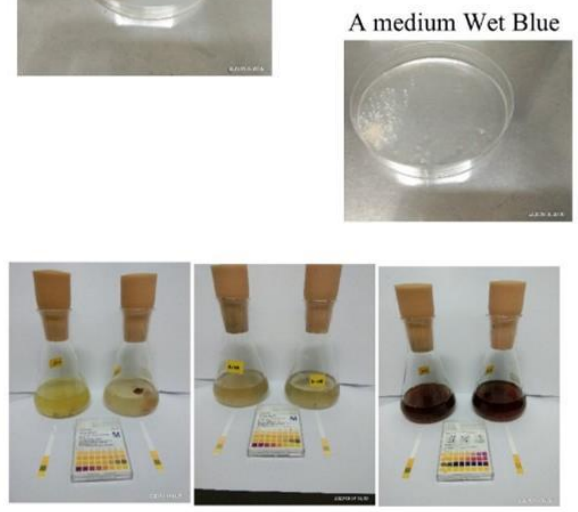

Isolation A medium left and B medium right. The Labels from left to right: Pickle Leather, Wet Blue Leather, and Artickle Leather.

Each liquid medium centrifuge as $1.5 \mathrm{ml}$ plastic

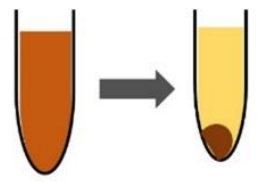

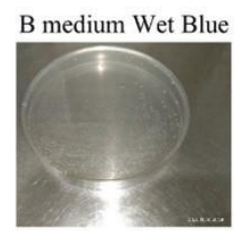
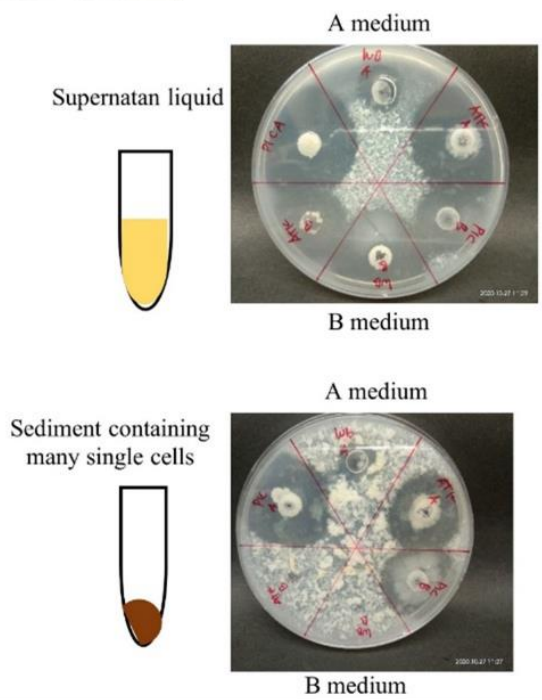

Fig 3. Isolation drop in well solid medium from A and B medium on $2 \%$ skim milk commercialwater $1.5 \%$ agar. 


\subsection{The pH Value of the Isolation Medium was Associated with Microbial Gelatinize and Protease with Leather Defects}

A modified method of a $15 \mathrm{~cm}$ test tube was used to demonstrate the protease ability. Onetest tube filled with nitrogen and water agar solid media in 3 or 2 layers. The 3 layers sequence is as follows: the bottom is a $2 \%$ commercial skimmed at the bottom $1.5 \%$ agar in the middle, and $13 \%$ bovine gelatine at the top. Meanwhile, the two layers were arranged as follows: $1.5 \%$ agar at the bottom and $2 \%$ commercial skimmed at the top Furthermore, the $20 \mu \mathrm{L}$ liquid two methods leather defect microbial sources were added to the top layer and incubated at $38^{\circ} \mathrm{C}$. The gelatinize test showed a decrease in gels strength while the protease test showed clear zones in the test tube and plates. The gas production is shown in the test tube (Figure 4). Since the $\mathrm{pH}$ affects gas production in the test tube, the Universal $\mathrm{pH}$ paper from Merck was used.

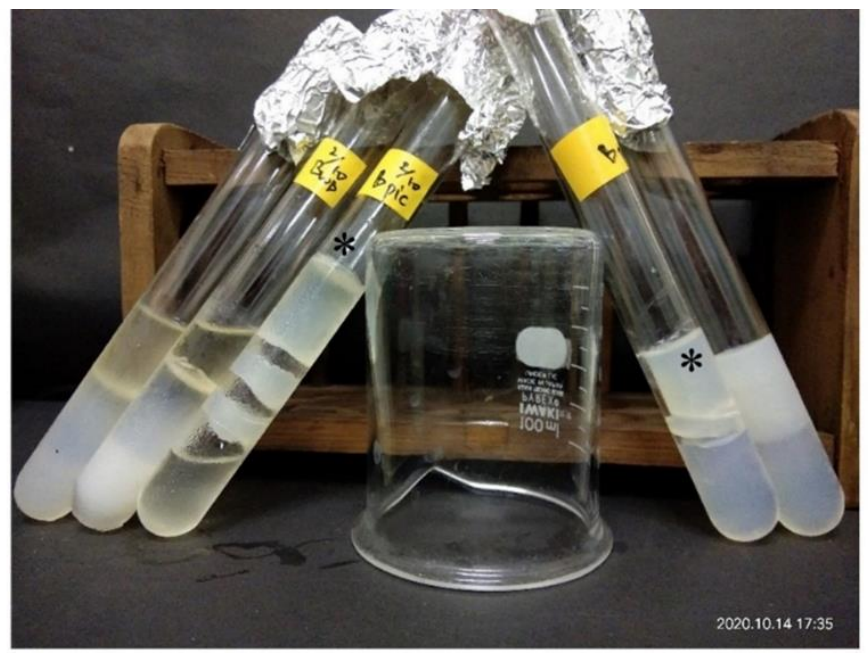

Fig. 4. Isolation B medium growth microbial of leather defect pickle produce gases. The gas will not appear if use zymography

\section{Results}

\subsection{Simple Isolation Method and Its Modification}

The isolation of leather defect microbes formed on solid media (1.5\% agar) and enriched with $2 \%$ skimmed cow's milk. Meanwhile, there was interest in yellow glossy colonies rather than white colonies since the glossy yellow morphology appeared in white colonies earlier than changing to Glossy Yellow after 17 days (Figure 5). Hence, the colony was believed Staphylococcus aureus (putative) bacteria [10]. These bacteria are cultivated from Wet Blue leather defects and upper shoe articles (Figure 6).

Furthermore, the isolation method was improved using a centrifuge to collect extracellular protease protein pool which has not been conducted in previous studies. This process was continued to isolate centrifuges using the Amicon Ultra Centrifugal Filter because it is the fastest, most economical, and also detect living cell microbes. Meanwhile, the objective is to ensure that extracellular protein protease and the cells live to damage the healthy leather. Furthermore, the second isolation method medium B showed that the blue colony changed color from white to yellow-white after incubation for 17 days and was suspected to be Staphylococcus aureus. The results of the scratches from the second isolation 
method on $2 \%$ solid media of commercial skimmed milk were medium A, namely glossy yellow (article) together with white colonies (pickle), and medium B namely yellow-white (wet blue), white (pickle), and glossy yellow (article) colonies (Figure-7).

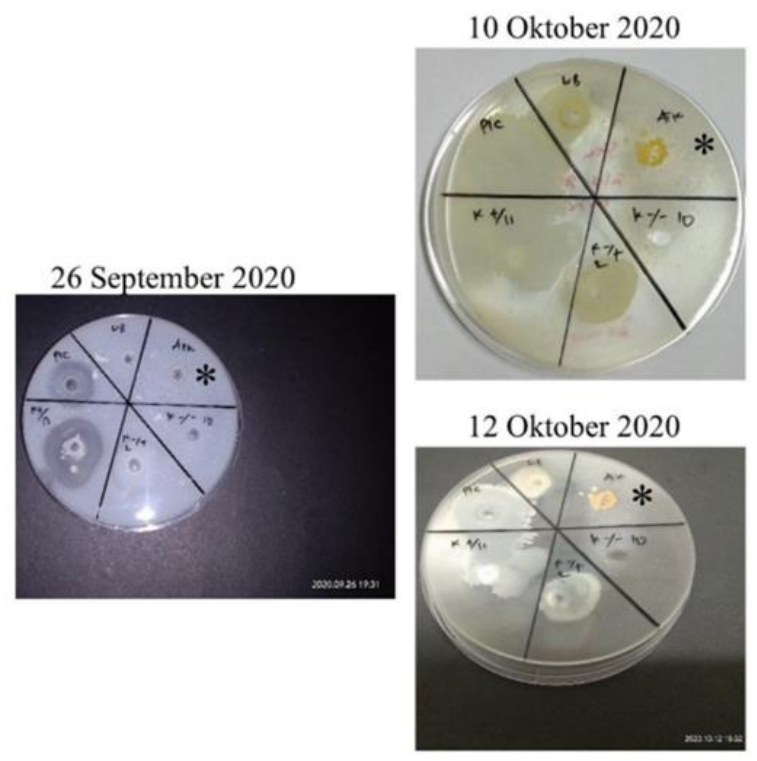

Fig. 5. Time changing white colony from wet blue and artickle to be yellow white from A medium as like Staphylococcus aureus (* sign). The bacteril colonies color were changed on 17 days from white to yellow in skim commercial
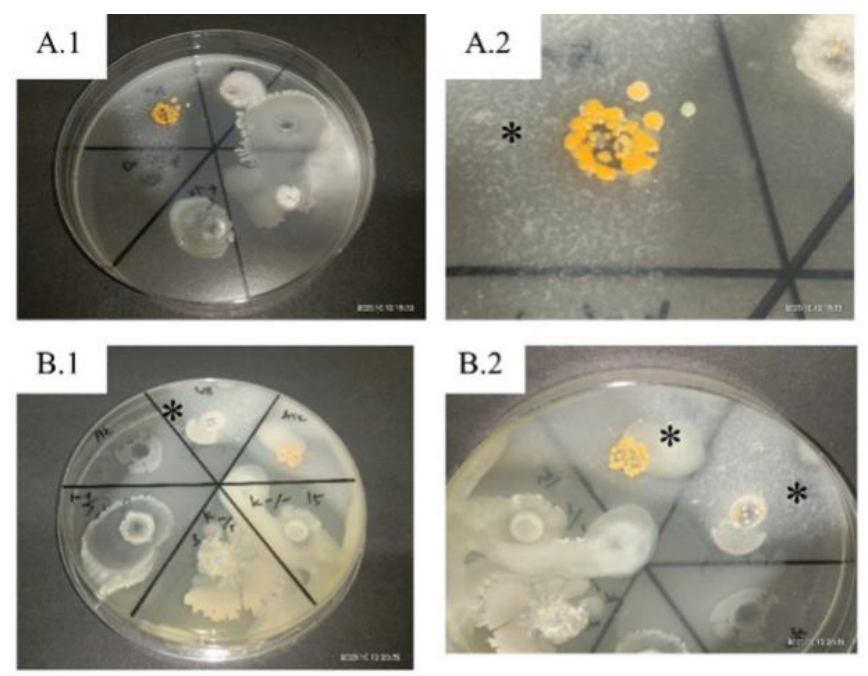

Fig. 6. The yellow glossy from A and B medium grown $2 \%$ skim commercial-minimal mineral medium. The yellow glossy as like Staphylococcus aureus (* sign) from wet blue sample from B medium able to grow even though one colony. Both yellow glossy bacterial grow without degraded skim commercial protein. 

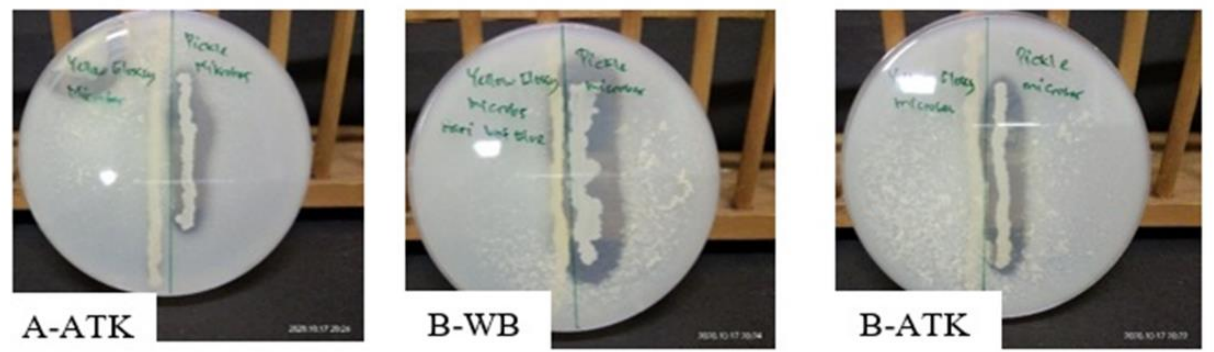

Fig. 7. Yellow glossy microbial. A-ATK is A medium yellow microbial from artickle and white microbial from pickle. B-WB and B-ATK are yellow microbial from wet blue and artickle, and white microbial from pickle

\subsection{Protease Benefits from Microbial Leather Defects}

Leather is a piece of clothing or raw material used by humans since ancient times and is more expensive than cotton cloth. Meanwhile, the decline in leather quality or raw materials caused by microbes is called a leather defect. The leather defect microbes were isolated to achieve the metabolomic mechanisms by which the microbes damage the leather, namely pickle, wet blue, and article. Furthermore, isolating the detected microbes using extracellular ability through microbial metabolomics was investigated by protease test using substrate variations. In this study, gelatinize such as skimmed milk and gelatine protease test were used, while the leather chemical processing known as microbial proteinase collagen was used to create leather defects. The results showed that the mechanisms target of the microbial leather defects produced proteases and gelatinizes. The major metabolomics enzymes of protease and gelatinize using a test tube layer with a slight difference of zymography were shown as $13 \%$ gelatine water agar, $2 \%$ commercial skimmed milk, and water $1.5 \%$ agar. Moreover, all the $13 \%$ gelatine test tubes showed positive, therefore, their ability at room temperature decreased the strength of the gels. Furthermore, the $2 \%$ test tube of positive skimmed milk with a clear zone that appears for more than 24 hours. These tests are shown in Figure $8 \mathrm{~A}$ and $\mathrm{B}$.
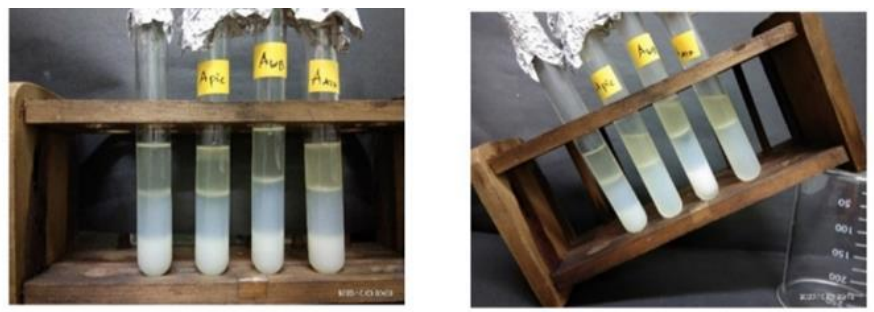

Gelatinase test Amedium 3 layers (13\% gelatine-water. Water-1.5\% agar, and $2 \%$ skim milk commercial) from left to right: control,

Fig. 8 A. Gelatinase test A Medium; Gelatinase test are positive 

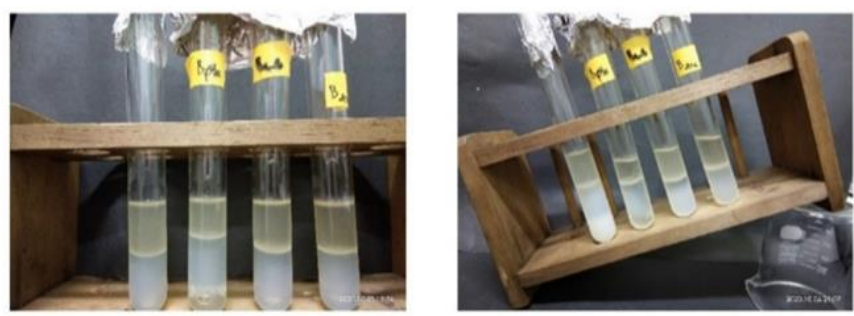

Gelatinase test B medium 3 layers (13\% gelatine-water. Water-1.5\% agar, and $2 \%$ skim milk commercial) from left to right: control,

Fig. 8 B. Gelatinase test B Medium; Gelatinase test are positive

\subsection{Protease Activity of Microbial Leather Defects}

Hiding or skinning animals after the tanning process is incredible. The leather tanning requires a long preservation process, therefore, the microbes grow to cause leather defects and also perforate and loosen the collagen fibers. Furthermore, the slow growth of microbes simultaneously changes the $\mathrm{pH}$ from acidic to neutral or alkaline as shown in Table 2. The microbial leather defects protease remained active and grew at different $\mathrm{pH}$ values of acid 5 and 6, neutral 7, as well as articles 8 and 9. It was developed and demonstrated in a test tube glass that no electrophoretic basis for the selection of proteases was available. The medium used was $2 \%$ commercial skimmed milk and water-agar (agar base $1.5 \%$ ). The results are shown in Table 3 and Figure 9.

Table 2. Evaluation in the $\mathrm{pH}$ value of the grown medium for microbial skin defects

\begin{tabular}{|c|c|c|c|c|}
\hline Days & Date & Leather steps & Medium A & Medium B \\
\hline 1. & August $12^{\text {th }}, 2020$ & Pickle & 5 & 5 \\
\hline & & Wet Blue & 5 & 5 \\
\hline & & Article & 5 & 5 \\
\hline & & & & 6 \\
\hline 2. & August $19^{\text {th }}, 2020$ & Pickle & 6 & 6 \\
\hline & & Wet Blue & 8 & 5 \\
\hline & & Article & 7 & \\
\hline & & & & 7 \\
\hline 3. & September $23^{\text {rd }}, 2020$ & Pickle & 8 & 7 \\
\hline & & Wet Blue & 8 & 7 \\
\hline & & Article & 8 & 8 \\
\hline & & & 9 & 8 \\
\hline 4. & October $17^{\text {th }}, 2020$ & Pickle & 9 & \\
\hline & & Wet Blue & 9 & 8 \\
\hline & & Article & 9 & 8 \\
\hline & & & 9 & 9 \\
\hline 5. & November $20^{\text {th }}, 2020$ & Pickle & 9 & \\
\hline & & Wet Blue & 9 & \\
\hline & & Article & 9 & \\
\hline
\end{tabular}


Table 3. Protease testing: $13 \%$ gelatinize and clear zone on $2 \%$ commercial skimmed milk and

\begin{tabular}{|l|c|c|c|c|c|c|}
\hline \multirow{2}{*}{$\begin{array}{c}\text { Leather } \\
\text { steps }\end{array}$} & $\begin{array}{c}\text { Medium A } \\
\text { gelatinize }\end{array}$ & $\begin{array}{c}\text { clear zone } \\
\text { at } 2 \% \\
\text { skimmed } \\
\text { milk } \\
\text { commercial }\end{array}$ & $\begin{array}{c}2 \% \\
\text { gelatine }\end{array}$ & $\begin{array}{c}13 \% \\
\text { gelatinize }\end{array}$ & $\begin{array}{c}\text { clear zone } \\
\text { at } 2 \% \\
\text { skimmed } \\
\text { milk } \\
\text { commercial }\end{array}$ & $\begin{array}{c}2 \% \\
\text { gelatine }\end{array}$ \\
\hline Pickle & Positive & Positive & Positive & Positive & Positive & Positive \\
\hline $\begin{array}{l}\text { Wet } \\
\text { Blue }\end{array}$ & Positive & Positive & Positive & Positive & Negative & Positive \\
\hline Article & Positive & Negative & Positive & Positive & Negative & Positive \\
\hline
\end{tabular}

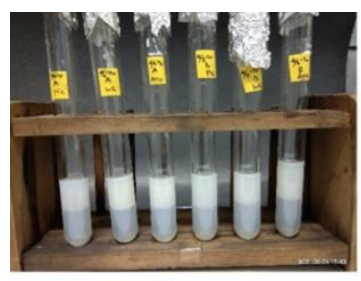

0 day

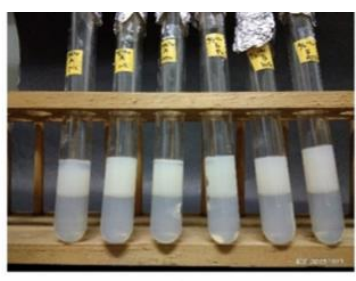

1 day

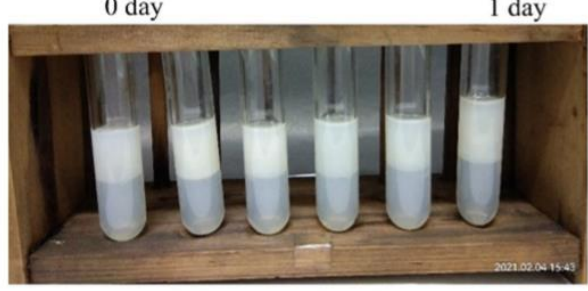

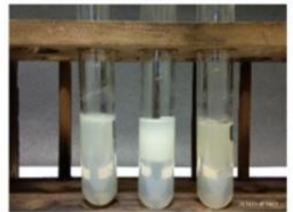

10 days $\mathrm{A}$ Medium

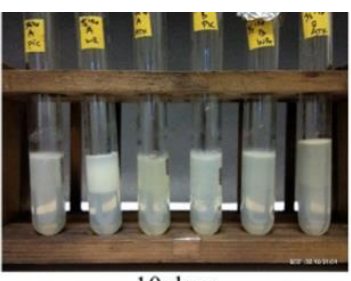

10 days

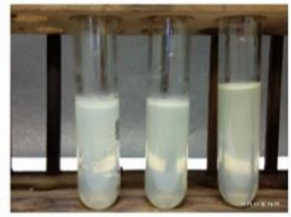

10 days $\mathrm{B}$ Medium

0 day $\mathrm{A}$ and $\mathrm{B}$ medium

Fig. 9. Protease test A medium and B medium on $2 \%$ skim commercial-water 1,5\% agar (first layer) and water $1,5 \%$ agar (second layer) with $20 \mu \mathrm{L}$ isolate A and B medium. Opaque color of skim change to transparent like water $1,5 \%$ agar test are positive. After 10 days

\section{Discussion}

\subsection{Evaluation of Isolating Microbial Proteases from the Isolation of Media A and $B$}

Two methods of isolating microbial leather defects were applied in this study. The results of the first or conventional method gave similar microbial color morphologically, namely white opaque and dark brown fungi pickle leather medium B with a nitrogen source of $2 \%$ bovine gelatine (Figure 6). Moreover, the second method gave a bigger morphological difference when the nitrogen source used was $2 \%$ commercial skimmed milk with a $10 \mu \mathrm{L}$ inoculum placed in a well-molded hot glass. This method showed that glossy yellow is from medium $\mathrm{A}$ and $\mathrm{B}$ of the inoculum article leather defect. Although the glossy yellow colonies formed unclear areas in commercial skimmed milk media, there is an expectation of microbes to become protease by replacing the nitrogen substrate in a solid medium such as analytical skimmed milk or a more specific nitrogen source. In contrast to pickle white colonies inoculated in $2 \%$ gelatine and commercial skimmed milk showing a larger clear area, there 
is a possibility that these microbes belong to the genus of protease bacteria with lobateshaped colony edge morphology [11].

\subsection{Glossy Yellow, Yellow White, and White from Microbial Leather Defects}

The present microbial leather defect colonies are unique because they hardly use commercial skimmed milk nutrients such as glossy yellow from the medium inoculum A. Based on the results, the two mechanisms by which glossy yellow grows such as yellow-white and white colonies include (1) catabolism of nutritional ingredients rather than skimmed milk protein and (2) absorbing the performance results of yellow-white microbes (putative Staphylococcus aureus and medium B wet blue) and white which are very active in remodeling skimmed milk protein to enhance the development of glossy yellow microbes [12].

Medium A is a minimum provider of phosphate buffer minerals needed as a metabolic enzyme cofactor, while medium B uses $1 / 200$ nutrient broth CM0001 which provides the minimum required vitamins as a coenzyme. Meanwhile, the results showed that the microbes which are a good source of protease are glossy yellow colonies isolated from the article sample, inoculum media A and B, while the gelatinize test yielded positive values.

\subsection{The $\mathrm{pH}$ Value and Best Protease}

The results showed that the production of a protease that withstands various $\mathrm{pHs}$ from acid to alkaline involved the use of medium A containing $0.07 \% \mathrm{~K}_{2} \mathrm{HPO}_{4}, 0.01 \% \mathrm{KH}_{2} \mathrm{PO}_{4}$, and $0.02 \% \mathrm{MgCl}_{2}$. This showed that using a minimal mineral medium is indispensable for producing extracellular proteases because almost all proteases are metalloenzymes [13], [14]. Meanwhile, the $2 \%$ gelatine used in this study as a nitrogen source to produce extracellular proteases has not been stated as the best nitrogen source concentration.

\section{Conclusion}

Protease is the main enzyme in all living things, especially in the animal kingdoms and microorganisms. Minerals in soil, water, or mining enhance this enzyme for both microorganisms and human beings. Meanwhile, mineral specimens that increase microbial proteases are more economical for humans. Therefore, a leather defect is suitable for getting protease microbes which are useful for human well-being.

The inspiration comes from my student TGU that accompanied Astinari Widyastuti from Unit Pelaksana Teknis Industri Kulit dan Produk Kulit Magetan, East Java and the student WPP that introduced me to Mrs. Dwita Indrarosa from Balai Besar Pelatihan Peternakan, Batu, Malang, East Java. Also, the student DIK introduced me to Eka Lusiana from Balai Besar Kulit, Karet, dan Plastik Yogyakarta, I am an alumnus of Gifu University who was supervised by Prof. Tomyuki Nakagawa and all Senseis who gave me their knowledge until I understood what a microorganism growth medium is. The author is grateful to the Indonesian government BPPDN scholarship award, especially for the Ministry of Education and Culture 2019 till now.

\section{References}

1. B. H. Cadirci, H. Ozgunay, C. Vural, and O. Yilmaz, "A new defect on leather: Microbial bio-film," J. Am. Leather Chem. Assoc., vol. 105, no. 04, 2010, [Online]. Available: https://journals.uc.edu/index.php/JALCA/article/view/3255/2506. 
2. E. Purnomo, Pengetahuan Dasar Teknologi Penyamakan Kulit. Yogyakarta, Indonesia: Departemen Perindustrian Republik Indonesia, Akademi Teknologi Kulit, Jl.Diponegoro No.101, Yogyakarta, 1985.

3. J. Skóra, B. Gutarowska, L. Stepien, A. Otlewska, and K. Pielech-Przybylska, "The evaluation of microbial contamination in the working environment of tanneries," Med. Pr., vol. 65, pp. 15-32, Feb. 2014, doi: 10.13075/mp.5893.2014.005.

4. A. Orlita, "Microbial biodeterioration of leather and its control: a review," Int. Biodeterior. Biodegradation, vol. 53, no. 3, pp. 157-163, Apr. 2004, doi: 10.1016/S0964-8305(03)00089-1.

5. Y.-Z. Zhang, L.-Y. Ran, C.-Y. Li, and X.-L. Chen, "Diversity, Structures, and CollagenDegrading Mechanisms of Bacterial Collagenolytic Proteases," Appl. Environ. Microbiol., vol. 81, no. 18, pp. 6098-6107, Sep. 2015, doi: 10.1128/AEM.00883-15.

6. M. Gautam and W. Azmi, "Screening and Isolation of Collagenase Producing Microorganism from Proteins Waste Found in Himalayan Region," J. Appl. Biotechnol. Reports, vol. 4, no. 1, pp. 558-565, 2017, [Online]. Available: http://www.biotechrep.ir/article_68978.html.

7. "MyCology Culture guide tips and techniques for culturing yeasts and filamentous fungitle." American Type Culture Collection, p. 35, 2013, [Online]. Available: https://www.atcc.org/ /media/PDFs/Culture Guides/Mycology_Guide.ashx.

8. M. D. Shepherd, M. K. Kharel, M. A. Bosserman, and J. Rohr, "Laboratory Maintenance of Streptomyces Species," Curr. Protoc. Microbiol., vol. 18, no. 1, p. Unit-10E.1, Aug. 2010, doi: 10.1002/9780471729259.mc10e01s18.

9. Y. Nagano et al., "Development of selective media for the isolation of yeasts and filamentous fungi from the sputum of adult patients with cystic fibrosis (CF)," J. Cyst. Fibros., vol. 7, no. 6, pp. 566-572, Nov. 2008, doi: 10.1016/j.jcf.2008.06.007.

10. U. TA, Taylor; CG, "Staphylococcus Aureus," in StatPearls, United State: Treasure Island (FL) : StatPearls Publishing, 2017-, 2020.

11. Microbiology Society, "Colony of Bateria morphology," 2021. https://microbiologysociety.org/why-microbiology-matters/what-ismicrobiology/bacteria/observing-bacteria-in-a-petri-dish.html.

12. P. D. Mary Jo Zimbro, B.S., MT (ASCP), David A. Power, M. (ASCP) Sharon M. Miller, B.S., M. (ASCP) George E. Wilson, MBA, B.S., and B. A. JulieA. Johnson, Eds., Manual of Microbial Culture Media, 2nd ed. Maryland, 2009.

13. M. B. Rao, A. M. Tanksale, M. S. Ghatge, and V. V Deshpande, "Molecular and biotechnological aspects of microbial proteases.," Microbiol. Mol. Biol. Rev., vol. 62, no. 3, pp. 597-635, Sep. 1998, [Online]. Available: http://www.ncbi.nlm.nih.gov/pubmed/9729602.

14. G. R., B. Q., and L. P., "Bacterial alkaline proteases: molecular approaches and industrial applications," Appl. Microbiol. Biotechnol., vol. 59, no. 1, pp. 15-32, Jun. 2002, doi: 10.1007/s00253-002-0975-y. 